\title{
TRANSMITTANCE INCREASE OF THE LOW ABSORBING MULTILAYER COATING
}

\author{
O. P. Kushnir (D) \\ Lviv National Agrarian University, Physics Department, \\ 1, Volodymyr Velykyj St., Dubliany, Lviv Region, UA-80381, Ukraine \\ (Received 20 November 2019; in final form 03 April 2020; accepted 18 April 2020; published online 14 May 2020)
}

\begin{abstract}
Analytical expressions are established for the complex thicknesses of two arbitrary layers of the low absorbing multilayer coating, at which zero value of the reflectance is achieved. Based on these relations, a numerical procedure is proposed for finding the thicknesses of one or more additional layers of the coating, which makes it possible to achieve a high transmittance for the chosen wavelength.

Key words: low absorbing multilayer coating, bandpass interference filter, interference mirror, half-wave spacer, high transmittance.
\end{abstract}

DOI: https://doi.org/10.30970/jps.24.2401

\section{INTRODUCTION}

Most of the developed methods for designing narrow bandpass interference filters are based on the use of transparent materials for layers [1-8]. However, it is not always possible to use materials that would have a very low extinction coefficient for a given wavelength. The use of low absorbing materials with an extinction coefficient of more than $10^{-3}$ leads to a significant decrease in the maximum transmittance of the filter, if it was designed for transparent materials. Therefore, it becomes necessary to develop methods for increasing transmittance of low absorbing multilayer coating by choosing the layers' thickness.

For multilayer coatings, many different methods have been developed to achieve zero reflectance and, accordingly, maximum transmittance for chosen wavelength $\lambda_{0}$. Among these methods, there are those that are based on the use of layers (transparent $[9,10]$ or low absorbing [11]) with arbitrary thicknesses and refractive indices, and only the thicknesses of two transparent layers are determined using established relations. Other methods use coatings with standard transparent layers whose phase thicknesses are multiples of $\pi / 2$ at $\lambda_{0}[1,2,12]$. In such coatings, in addition to quarter-wave layers, the so-called half-wave spacers with a phase thickness equal to $\pi$ at $\lambda_{0}$ are often used.

At the moment, methods for designing metal-dielectric coatings are also known, including filters, absorbers and antireflection coatings using both transparent and absorbing materials [13-17], which have some advantages over all-dielectric coatings.

In [18], the narrow bandpass filter $1.52\left|(\mathrm{HL})^{4} 2 \mathrm{H}(\mathrm{LH})^{4}\right| 1$ was considered in which all seventeen layers are low absorbing with complex refractive indices $\tilde{n}_{\mathrm{H}}=2.3-i 0.0002, \tilde{n}_{\mathrm{L}}=1.35-i 0.0002$. The transmittance of this filter, in which only one non-quarter-wave layer is used, reaches a value high enough for the chosen wavelength $\lambda_{0}=500 \mathrm{~nm}$ in the passband. For such filters, using a higher extinction coefficient leads to a significant decrease in the maximum transmittance (Fig. 1, dotted curve).
In order to achieve the maximum transmittance of an interference filter designed on the basis of low absorbing materials by determining the optimal thicknesses and numbers, for example, five layers, a numerical method is needed, which will require a lot of time for the calculation itself. To achieve high transmittance, another (more rational) way to solve this problem can be proposed. For this, it is necessary to obtain analytical relationships for the complex thicknesses of two layers, which for the desired coating provide a zero reflectance for arbitrary thicknesses of the other three layers. Using these relationships will significantly reduce the search time for the desired thicknesses and layer numbers to obtain a filter with a high transmittance. In addition, this procedure allows us to identify useful patterns that can be used to design filters based on low absorbing materials.

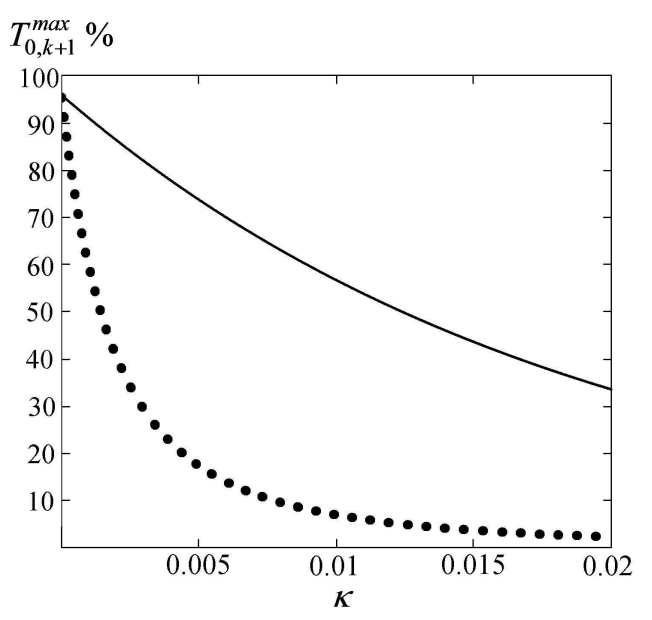

Fig. 1. Maximum transmittance $T_{0, k+1}^{\max }$ of two seventeen-layer filters $(k=17)$ with complex refractive indices $\tilde{n}_{\mathrm{H}}=2.3-i \kappa$, $\tilde{n}_{\mathrm{L}}=1.35-i \kappa$ versus extinction coefficient $\kappa$ : 1| $(\mathrm{HL})^{4} 2 \mathrm{H}(\mathrm{LH})^{4} \mid 1.52$ - dotted curve;

1) $\frac{4 d_{s} n_{\mathrm{H}}}{\lambda_{0}}$ HLHL 2H(LH) ${ }^{2}$ 2LHLH 2LHL $\frac{4 d_{m} n_{\mathrm{H}}}{\lambda_{0}} \mathrm{H} \mid 1.52$ - solid curve.

Thicknesses of layers $s$ and $m$, which depend on $\kappa$, are calculated using (14). (At $\kappa=0.0015: d_{s}=108.8 \mathrm{~nm}$, $\left.d_{m}=108.6 \mathrm{~nm} ; d_{\mathrm{H}}=54.3 \mathrm{~nm}, d_{\mathrm{L}}=92.6 \mathrm{~nm}\right)$. 


\section{O. P. KUSHNIR}

In this paper, we have developed a method of achieving high transmittance for a low absorbing coating using three or more non-quarter-wave layers. The feature of this method is the use of at least one layer with a thickness close to the thickness of a half-wave spacer. This approach allows us to design filters with high transmittance even for the case of the extinction coefficient of all layers more than $5 \times 10^{-3}$ (Fig. 1, solid curve).

\section{CONDITIONS FOR ACHIEVING ZERO REFLECTANCE AT NORMAL INCIDENCE}

Let us consider the $k$-layer coating with complex refractive indices of layers $\tilde{n}_{j}=n_{j}-i \kappa_{j}$ and their thicknesses $d_{j}(j=1,2, \ldots, k)$ on a transparent semiinfinite substrate with the refractive index $n_{k+1}$ while $n_{0}$ denotes the refractive index of the semi-infinite ambient medium. The amplitude reflectance of the coating $0,1, \ldots, k, k+1$ can be written as [19]

$$
\tilde{r}_{0, k+1}=\frac{\tilde{r}_{0, s}+\tilde{r}_{s, k+1} \tilde{h}_{0, s} e^{-2 i \tilde{\delta}_{s}}}{1-\tilde{r}_{s, 0} \tilde{r}_{s, k+1} e^{-2 i \tilde{\delta}_{s}}},
$$

where

$\tilde{r}_{s, k+1}=\frac{\tilde{r}_{s, m}+\tilde{r}_{m, k+1} \tilde{h}_{s, m} e^{-2 i \tilde{\delta}_{m}}}{1-\tilde{r}_{m, s} \tilde{r}_{m, k+1} e^{-2 i \tilde{\delta}_{m}}}$,

$\tilde{h}_{j, p}=\chi_{j, p} e^{i \gamma_{j, p}}=\tilde{t}_{j, p} \tilde{t}_{p, j}-\tilde{r}_{j, p} \tilde{r}_{p, j}$;

$\tilde{r}_{j, p}=\sigma_{j, p} e^{i \phi_{j, p}}, \tilde{t}_{j, p}=\tau_{j, p} e^{i \theta_{j, p}}$ is amplitude reflectance and transmittance of a part of the coating $j, j+1, \ldots$, $p-1, p$, when $p>j$, or $j, j-1, \ldots, p+1, p$, when $p<j$; $\chi_{j, p}, \sigma_{j, p}, \tau_{j, p}$ and $\gamma_{j, p}, \phi_{j, p}, \theta_{j, p}$ are respectively moduli and phases of the following complex quantities: $\tilde{h}_{j, p}, \tilde{r}_{j, p}$ and $\tilde{t}_{j, p}$. Complex amplitude reflectance $\tilde{r}_{j, p}$ and transmittance $\tilde{t}_{j, p}$ are determined according to the formulae:

$\tilde{r}_{j, p}=\frac{\tilde{N}_{j}-\tilde{N}_{p}}{\tilde{N}_{j}+\tilde{N}_{p}}, \tilde{t}_{j, p}=\frac{2 \tilde{N}_{j}}{\tilde{N}_{j}+\tilde{N}_{p}}$ when $|j-p|=1$,

or using recurrence relations

$\tilde{r}_{j, p}=\frac{\tilde{r}_{j, j \pm 1}+\tilde{r}_{j \pm 1, p} \exp \left(-i 2 \tilde{\delta}_{j \pm 1}\right)}{1+\tilde{r}_{j, j \pm 1} \tilde{r}_{j \pm 1, p} \exp \left(-i 2 \tilde{\delta}_{j \pm 1}\right)}$

and

$\tilde{t}_{j, p}=\frac{\tilde{t}_{j, j \pm 1} \tilde{t}_{j \pm 1, p} \exp \left(-i \tilde{\delta}_{j \pm 1}\right)}{1+\tilde{r}_{j, j \pm 1} \tilde{r}_{j \pm 1, p} \exp \left(-i 2 \tilde{\delta}_{j \pm 1}\right)}$ when $|j-p|>1$.

Here, "+" in the \pm refers to the condition $p>j+1$, and "_" refers to the condition $j>p+1$. In these expressions, $\tilde{N}_{j}$ is the generalized refractive index of the layer $j$ for $s$ polarization $\left(\tilde{N}_{j}=\tilde{N}_{j}^{\perp}=\tilde{n}_{j} \cos \tilde{\beta}_{j}\right)$, and its inverse value for $p$-polarization $\left(\tilde{N}_{j}=\tilde{N}_{j}^{\|}=\frac{\cos \tilde{\beta}_{j}}{\tilde{n}_{j}}\right) ; \tilde{\beta}_{j}$ being the angle of incidence at the boundary of $j /(j+1)$ media. Phase thicknesses of layers $s$ and $m$ :

$$
\begin{aligned}
& \tilde{\delta}_{s}=\frac{2 \pi d_{s}\left(n_{s}-i \kappa_{s}\right) \cos \tilde{\beta}_{s}}{\lambda}, \\
& \tilde{\delta}_{m}=\frac{2 \pi d_{m}\left(n_{m}-i \kappa_{m}\right) \cos \tilde{\beta}_{m}}{\lambda} .
\end{aligned}
$$

Let us consider the case of normal incidence when $\tilde{\beta}_{0}=$ $\tilde{\beta}_{1}=\ldots=\tilde{\beta}_{k}=0$. Based on $(1)$, the condition of zero reflectance $\left(\tilde{r}_{0, k+1}=0\right)$ for coating $0,1, \ldots, k, k+1$ is

$$
\tilde{r}_{0, s}+\tilde{r}_{s, k+1} \tilde{h}_{0, s} e^{-2 i \tilde{\delta}_{s}}=0
$$

or

$$
\tilde{r}_{0, s}+\frac{\tilde{r}_{s, m}+\tilde{r}_{m, k+1} \tilde{h}_{s, m} e^{-2 i \tilde{\delta}_{m}}}{1-\tilde{r}_{m, s} \tilde{r}_{m, k+1} e^{-2 i \tilde{\delta}_{m}}} \tilde{h}_{0, s} e^{-2 i \tilde{\delta}_{s}}=0 .
$$

Equation (3) can be rewritten as

$$
e^{2 i \tilde{\delta}_{s}}=\frac{\tilde{r}_{s, m} \tilde{h}_{0, s} e^{2 i \tilde{\delta}_{m}}+\tilde{r}_{m, k+1} \tilde{h}_{s, m} \tilde{h}_{0, s}}{\tilde{r}_{0, s} \tilde{r}_{m, s} \tilde{r}_{m, k+1}-\tilde{r}_{0, s} e^{2 i \tilde{\delta}_{m}}}
$$

and

$$
e^{2 i \tilde{\delta}_{m}}=\frac{\tilde{r}_{0, s} \tilde{r}_{m, s} \tilde{r}_{m, k+1} e^{2 i \tilde{\delta}_{s}}-\tilde{r}_{m, k+1} \tilde{h}_{s, m} \tilde{h}_{0, s}}{\tilde{r}_{0, s} e^{2 i \tilde{\delta}_{s}}+\tilde{r}_{s, m} \tilde{h}_{0, s}} .
$$

We also write down the equations

$$
e^{-2 i \tilde{\delta}_{s}^{*}}=\frac{\tilde{r}_{s, m}^{*} \tilde{h}_{0, s}^{*} e^{-2 i \tilde{\delta}_{m}^{*}}+\tilde{r}_{m, k+1}^{*} \tilde{h}_{s, m}^{*} \tilde{h}_{0, s}^{*}}{\tilde{r}_{0, s}^{*} \tilde{r}_{m, s}^{*} \tilde{r}_{m, k+1}^{*}-\tilde{r}_{0, s}^{*} e^{-2 i \tilde{\delta}_{m}^{*}}}
$$

and

$$
e^{-2 i \tilde{\delta}_{m}^{*}}=\frac{\tilde{r}_{0, s}^{*} \tilde{r}_{m, s}^{*} \tilde{r}_{m, k+1}^{*} e^{-2 i \tilde{\delta}_{s}^{*}}-\tilde{r}_{m, k+1}^{*} \tilde{h}_{s, m}^{*} \tilde{h}_{0, s}^{*}}{\tilde{r}_{0, s}^{*} e^{-2 i \tilde{\delta}_{s}^{*}}+\tilde{r}_{s, m}^{*} \tilde{h}_{0, s}^{*}},
$$

which are complex conjugate to equations (4) and (5), respectively. Taking into account expressions (2), the left-hand sides of equations (6), (7) can be written as: $e^{-2 i \tilde{\delta}_{s}^{*}}=e^{-2 i \tilde{\delta}_{s}} e^{\frac{8 \pi d_{s} \kappa_{s}}{\lambda}} ; e^{-2 i \tilde{\delta}_{m}^{*}}=e^{-2 i \tilde{\delta}_{m}} e^{\frac{8 \pi d_{m} \kappa_{m}}{\lambda}}$. For low absorbing thin layers $s, m$, when extinction coefficients take small values $\left(\kappa_{s, m}<0.01\right)$, the approximate equalities are true: $e^{-2 i \tilde{\delta}_{s}^{*}} \approx e^{-2 i \tilde{\delta}_{s}}, e^{-2 i \tilde{\delta}_{m}^{*}} \approx e^{-2 i \tilde{\delta}_{m}}$. Then, instead of equations (6), (7), we can write the equations:

$$
e^{2 i \tilde{\delta}_{s}}=\frac{\tilde{r}_{0, s}^{*} \tilde{r}_{m, s}^{*} \tilde{r}_{m, k+1}^{*}-\tilde{r}_{0, s}^{*} e^{-2 i \tilde{\delta}_{m}}}{\tilde{r}_{s, m}^{*} \tilde{h}_{0, s}^{*} e^{-2 i \tilde{\delta}_{m}}+\tilde{r}_{m, k+1}^{*} \tilde{h}_{s, m}^{*} \tilde{h}_{0, s}^{*}}
$$

and

$$
e^{2 i \tilde{\delta}_{m}}=\frac{\tilde{r}_{0, s}^{*} e^{-2 i \tilde{\delta}_{s}}+\tilde{r}_{s, m}^{*} \tilde{h}_{0, s}^{*}}{\tilde{r}_{0, s}^{*} \tilde{r}_{m, s}^{*} \tilde{r}_{m, k+1}^{*} e^{-2 i \tilde{\delta}_{s}}-\tilde{r}_{m, k+1}^{*} \tilde{h}_{s, m}^{*} \tilde{h}_{0, s}^{*}} .
$$

The solutions of the system of equations (4), (8) with respect to $\tilde{\delta}_{m}$ and $(5),(9)$ with respect to $\tilde{\delta}_{s}$ are

$$
\tilde{\delta}_{s}^{ \pm}=\frac{1}{2 i} \ln \left(\frac{B_{s} \pm \sqrt{C_{s}}}{\tilde{A}_{s}}\right)+\pi j_{s}, \quad j_{s}=1,2, \ldots ;
$$

$$
\tilde{\delta}_{m}^{ \pm}=\frac{1}{2 i} \ln \left(\frac{B_{m} \pm \sqrt{C_{m}}}{\tilde{A}_{m}}\right)+\pi j_{m}, \quad j_{m}=1,2, \ldots
$$

where 


$$
\begin{aligned}
& B_{s}=-\sigma_{0, s}^{2}+\chi_{0, s}^{2} \chi_{s, m}^{2} \sigma_{m, k+1}^{2}+\sigma_{0, s}^{2} \sigma_{m, k+1}^{2} \sigma_{m, s}^{2}-\chi_{0, s}^{2} \sigma_{s, m}^{2} \\
& B_{m}=\sigma_{0, s}^{2}-\chi_{0, s}^{2} \chi_{s, m}^{2} \sigma_{m, k+1}^{2}+\sigma_{0, s}^{2} \sigma_{m, k+1}^{2} \sigma_{m, s}^{2}-\chi_{0, s}^{2} \sigma_{s, m}^{2} \\
& \tilde{A}_{s}=2 \tilde{r}_{0, s} \tilde{h}_{0, s}^{*}\left(\sigma_{m, k+1}^{2} \tilde{r}_{m, s} \tilde{h}_{s, m}^{*}+\tilde{r}_{s, m}^{*}\right) \\
& \tilde{A}_{m}=2 \tilde{r}_{m, k+1}^{*}\left(\chi_{0, s}^{2} \tilde{r}_{s, m} \tilde{h}_{s, m}^{*}+\sigma_{0, s}^{2} \tilde{r}_{m, s}^{*}\right) \\
& C_{s}=B_{s}^{2}-\left|A_{s}\right|^{2}, C_{m}=B_{m}^{2}-\left|A_{m}\right|^{2} .
\end{aligned}
$$

In order to determine the thicknesses of layers $s$ and $m$, we can first write down the corresponding relations for complex thicknesses instead of equations (10), (11) using (2):

$$
\begin{gathered}
\tilde{d}_{s}^{ \pm}=\frac{\lambda}{2 \pi \tilde{n}_{s}}\left(\frac{1}{2 i} \ln \left(\frac{B_{s} \pm \sqrt{C_{s}}}{\tilde{A}_{s}}\right)+\pi j_{s}\right), \quad j_{s}=1,2, \ldots ; \\
\tilde{d}_{m}^{ \pm}=\frac{\lambda}{2 \pi \tilde{n}_{m}}\left(\frac{1}{2 i} \ln \left(\frac{B_{m} \pm \sqrt{C_{m}}}{\tilde{A}_{m}}\right)+\pi j_{m}\right), \quad j_{m}=1,2, \ldots .
\end{gathered}
$$

For such complex thicknesses, zero reflectance $\left(\tilde{r}_{0, k+1}=0\right)$ is achieved, but if $\operatorname{Im}\left(\tilde{d}_{s, m}\right) \neq 0$, then they have no physical meaning. In order to achieve the reflectance close to zero and accordingly increase the transmittance, the thickness of one or more layers can be used as a variable parameter. For certain values of these parameters, the imaginary parts of expressions (12), (13) for thicknesses become close to zero $\left(\operatorname{Im}\left(\tilde{d}_{s, m}^{ \pm}\right) \approx 0\right)$. In this case, for normal incidence, the transmittance $T_{0, k+1}=\frac{n_{k+1}}{n_{0}} \tilde{t}_{0, k+1} \tilde{t}_{0, k+1}^{*}$ and reflectance $R_{0, k+1}=$ $\tilde{r}_{0, k+1} \tilde{r}_{0, k+1}^{*}$ calculated for positive real thicknesses

$$
d_{s, m}^{ \pm}=\operatorname{Re}\left(\tilde{d}_{s, m}^{ \pm}\right)
$$

take respectively high and close to zero values.

\section{NUMERICAL EXAMPLES}

Let us consider $k$-layer coating $(k=2 p+1)$ such as an interference mirror on the glass substrate with refractive index $n_{k+1}=1.52$ :

$$
1\left|\mathrm{H}(\mathrm{LH})^{p}\right| 1.52 .
$$

All layers of such a coating are made using two low absorbing materials with refractive indices $\tilde{n}_{\mathrm{H}}=n_{\mathrm{H}}-$ $i \kappa_{\mathrm{H}}$ and $\tilde{n}_{\mathrm{L}}=n_{\mathrm{L}}-i \kappa_{\mathrm{L}}$. For the chosen wavelength $\lambda_{0}$, all layers are quarter-wave with thicknesses $d_{\mathrm{H}}=\frac{\lambda_{0}}{4 n_{\mathrm{H}}}$ and $d_{\mathrm{L}}=\frac{\lambda_{0}}{4 n_{\mathrm{L}}}$. In such coatings with a large number of layers $k$, the transmittance $T_{0, k+1}$ in a certain spectral range, which includes wavelength of $\lambda_{0}$, is close to zero.
Our task is to maximize the transmittance $T_{0, k+1}$ at wavelength $\lambda_{0}$ so that a narrow bandpass filter can be obtained. Therefore, to maintain low transmittance outside the filter passband, it is necessary to change the thickness of only a few layers. According to the method described in the previous section, let us consider three ways to achieve the maximum value $T_{0, k+1}$ :

a) the variable parameter is the thickness $d_{u}$ of the layer with number $u$;

b) the variable parameter is the thicknesses $d_{u}, d_{\nu}$ of the layers with numbers $u, \nu$;

c) the variable parameter is the thicknesses $d_{u}, d_{\nu}, d_{w}$ of the layers with numbers $u, \nu, w$.

In all these methods, the layer numbers $s$ and $m$, whose thicknesses of which are calculated according to formulas (14), must be chosen so as to give high value $T_{0, k+1}$.

In method a), it is necessary to find the dependence of the transmittance $T_{0, k+1}$ on $d_{u}$ for different numbers $u$. This dependence shows a periodic increase in the transmittance in some narrow intervals of thickness $d_{u}$ (Fig. 2a, 3c), which include values that are multiples of $2 d_{\mathrm{L}}$, when $u$ is the layer with the refractive index $\tilde{n}_{\mathrm{L}}$. In the case when $u$ is the layer with the refractive index $\tilde{n}_{\mathrm{H}}$, it is possible to observe a periodic increase in the transmittance in narrow intervals $d_{u}$ containing values that are multiples of $2 d_{\mathrm{H}}$ (Fig. $\left.3 \mathrm{a}\right)$. In both cases, the high transmittance $T_{0, k+1}$ are also observed at a small thickness $d_{u}$ (Fig. 2b). Constants $2 d_{\mathrm{L}, \mathrm{H}}\left(2 d_{\mathrm{L}}\right.$ or $\left.2 d_{\mathrm{H}}\right)$ are the thicknesses of half-wave spacers for the corresponding material, which are often used in the design of filters based on transparent layers [1,2]. A detailed examination of narrow intervals for $d_{u}$, inside of which there 


\section{O. P. KUSHNIR}

are constants $2 d_{\mathrm{L}, \mathrm{H}}$, shows that for some numbers $u$, the constants $2 d_{\mathrm{L}, \mathrm{H}}$ correspond to local minima of the transmittance, and for others, maxima (Fig. 3b, 3d). As an example of achieving high transmittance in method a), consider a twenty-three layer filter (Fig. 4, solid curve; Fig. 5a):

$$
1\left|\mathrm{HLH} \frac{4 d_{s} n_{\mathrm{L}}}{\lambda_{0}} \mathrm{~L}(\mathrm{HL})^{4} 1.9986 \mathrm{HL}(\mathrm{HL})^{3} \frac{4 d_{m} n_{\mathrm{H}}}{\lambda_{0}} \mathrm{HLH}\right| 1.52
$$

$s=4, m=21, u=13$;

and twenty nine-layer filter (Fig. 4 , dash-dotted curve)

$$
\text { 1| } \mathrm{HLH} \frac{4 d_{s} n_{\mathrm{L}}}{\lambda_{0}} \mathrm{~L}(\mathrm{HL})^{4} \mathrm{H} 1.9996 \mathrm{~L}(\mathrm{HL})^{5} \frac{4 d_{m} n_{\mathrm{H}}}{\lambda_{0}} \mathrm{H}(\mathrm{LH})^{2} \mid 1.52
$$

$s=4, m=25, u=14$,

at $\tilde{n}_{\mathrm{H}}=4.3-i 0.0015, \quad \tilde{n}_{\mathrm{L}}=1.46-i 0.0001$, $\lambda_{0}=500 \mathrm{~nm}$. According to (14), the thicknesses of layers $s$ and $m$ are calculated: $d_{s}=171.0 \mathrm{~nm}, d_{m}=58.3 \mathrm{~nm}$ when choosing the thickness $d_{u}=58.1 \mathrm{~nm}$ for the filter (16) and $d_{s}=171.0 \mathrm{~nm}, d_{m}=58.2 \mathrm{~nm}$ when choosing the thickness $d_{u}=171.2 \mathrm{~nm}$ for the filter (17). For both filters, the thicknesses of the quarter-wave layers $\mathrm{H}$ and $\mathrm{L}$ are equal to: $d_{\mathrm{H}}=29.1 \mathrm{~nm}$ and $d_{\mathrm{L}}=85.6 \mathrm{~nm}$.

In the filter formulas (16), (17), expressions $\frac{4 d_{s} n_{\mathrm{L}}}{\lambda_{0}}, \frac{4 d_{m} n_{\mathrm{H}}}{\lambda_{0}}$ or numerical values that appear before the capital letters $\mathrm{H}$ or $\mathrm{L}$ mean the ratio of the phase thickness of the corresponding layer $\mathrm{H}$ or $\mathrm{L}$ to $\pi / 2$. If such designations are absent before the capital letters $\mathrm{H}$ or $\mathrm{L}$, then this means that the phase thickness of the corresponding layer is equal to $\pi / 2$ (quarter-wave layer). The designation (HL) ${ }^{4}$ indicates the repetition of a sequence of layers. The numerical values of 1 and 1.52 , which are at the beginning and at the end of the formula, are the refractive indices of air and a glass substrate.

Figure 6 shows the dependence of the maximum transmittance $T^{\max }$ (among the transmittances $T_{0, k+1}$ of twenty-three layer coatings (15) with a half-wave layer $u$ and two layers $s, m$ with thicknesses $d_{s, m}$ (14) calculated for all possible numbers $u$ ) on the numbers $s, m$ at $\lambda_{0}=500 \mathrm{~nm}$. For such coatings, the highest values of $T^{\max }(82 \%, 84 \%, 82 \%)$ are achieved, respectively, for such numbers $s, m: s=4, m=20$ (at $u=12$ ); $s=4$, $m=12$ (at $u=20) ; s=12, m=20$ (at $u=4)$. But due to the fact that in the passband of coatings with such sets of numbers there is a significant oscillation of the transmittance (Fig. 4 dotted curve), in the example of filter calculation (16), a coating with other numbers $s=4, m=21$ (at $u=13$ ) was chosen. For such a coating, the mentioned oscillation is absent and the transmittance reaches a value that is high enough $\left(T_{0, k+1}^{\max } \approx 67 \%\right)$.

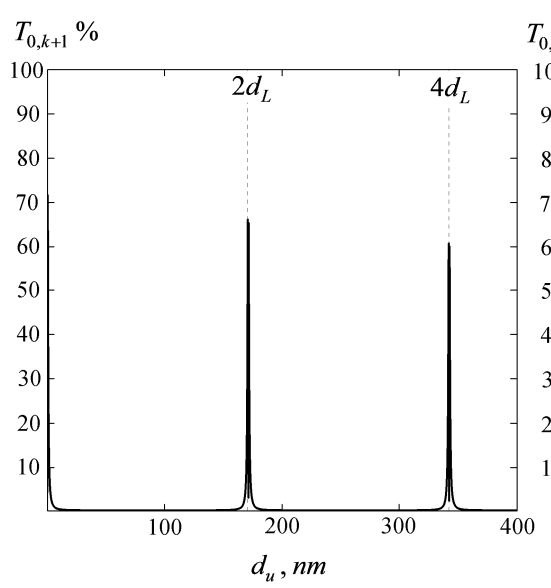

a)

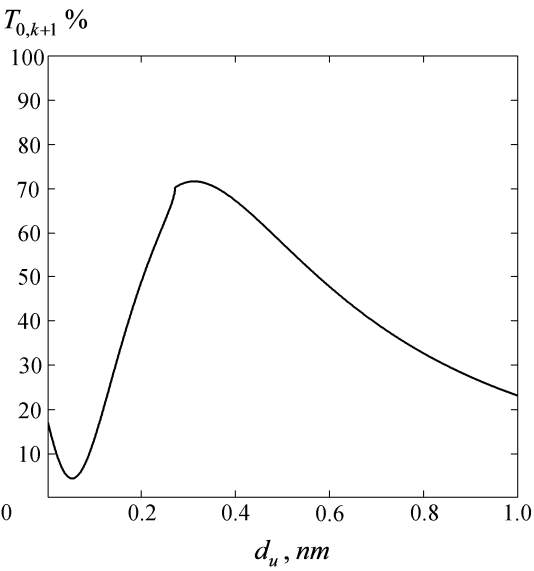

b)

Fig. 2. Transmittance $T_{0, k+1}$ of the twenty-three-layer coating $(k=23)$

1| $\mathrm{HLH} \frac{4 d_{s} n_{\mathrm{L}}}{\lambda_{0}} \mathrm{~L}(\mathrm{HL})^{4} \mathrm{H} \frac{4 d_{u} n_{\mathrm{L}}}{\lambda_{0}} \mathrm{~L}(\mathrm{HL})^{3} \frac{4 d_{m} n_{\mathrm{H}}}{\lambda_{0}} \mathrm{HLH} \mid 1.52$

versus thickness $d_{u}(u=14)$. Thicknesses $d_{s}$ and $d_{m}(s=4, m=21)$, which depend on $d_{u}$, are calculated according to $(14)$ at $\tilde{n}_{\mathrm{H}}=4.3-i 0.0015, \tilde{n}_{\mathrm{L}}=1.46-i 0.0001, \lambda_{0}=500 \mathrm{~nm}, d_{\mathrm{H}}=29.1 \mathrm{~nm}, d_{\mathrm{L}}=85.6 \mathrm{~nm}$. 


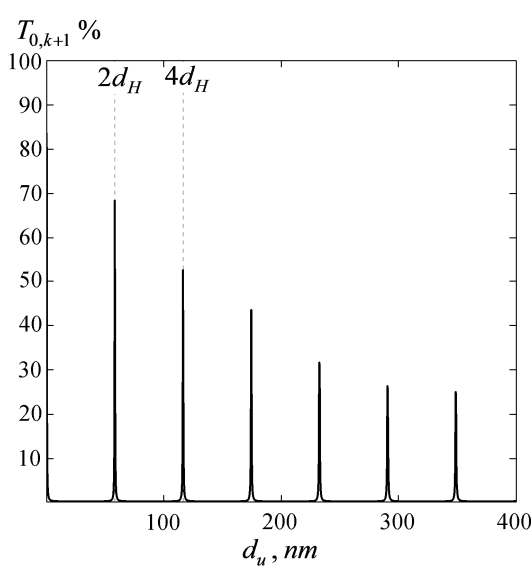

a)

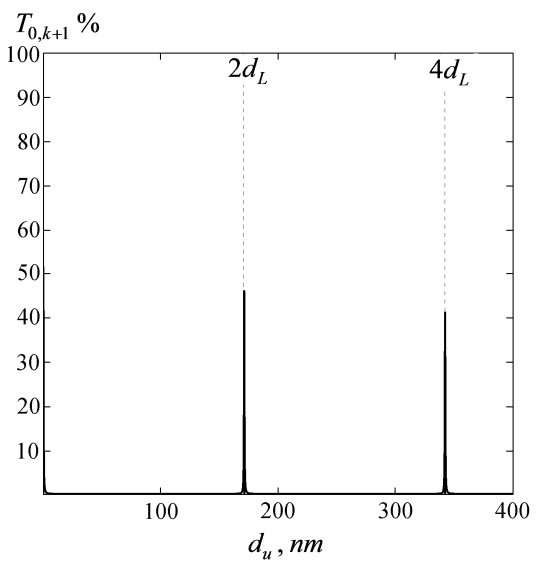

c)

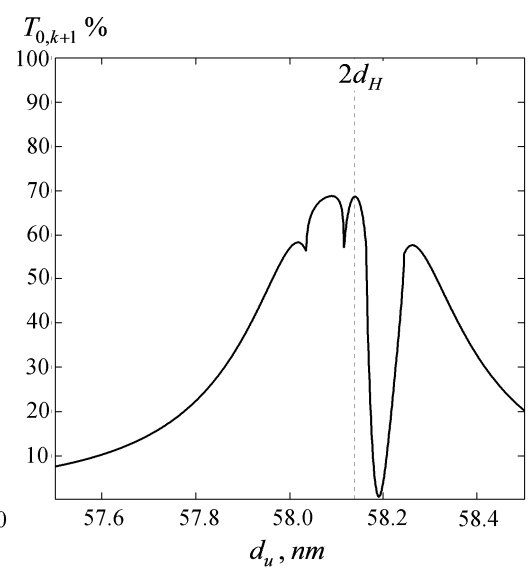

b)

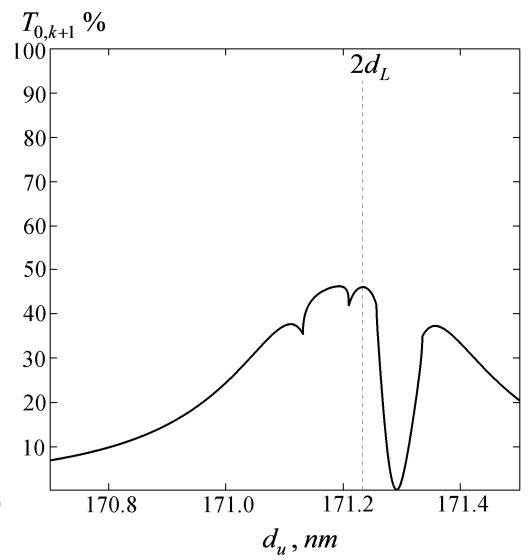

d)

Fig. 3. Transmittance $T_{0, k+1}$ of two $k$-layer coatings versus thickness $d_{u}$ :

a), b) $1\left|\mathrm{HLH} \frac{4 d_{s} n_{\mathrm{L}}}{\lambda_{0}} \mathrm{~L}(\mathrm{HL})^{4} \frac{4 d_{u} n_{\mathrm{H}}}{\lambda_{0}} \mathrm{HL}(\mathrm{HL})^{3} \frac{4 d_{m} n_{\mathrm{H}}}{\lambda_{0}} \mathrm{HLH}\right| 1.52$

$k=23, s=4, m=21, u=13$;

c), d) $1\left|\mathrm{HLH} \frac{4 d_{s} n_{\mathrm{L}}}{\lambda_{0}} \mathrm{~L}(\mathrm{HL})^{4} \mathrm{H} \frac{4 d_{u} n_{\mathrm{L}}}{\lambda_{0}} \mathrm{~L}(\mathrm{HL})^{5} \frac{4 d_{m} n_{\mathrm{H}}}{\lambda_{0}} \mathrm{H}(\mathrm{LH})^{2}\right| 1.52$

$k=29, s=4, m=25, u=14$.

Thicknesses $d_{s}$ and $d_{m}$, which depend on $d_{u}$, are calculated according to (14) at $\tilde{n}_{\mathrm{H}}=4.3-i 0.0015, \tilde{n}_{\mathrm{L}}=1.46-i 0.0001$, $\lambda_{0}=500 \mathrm{~nm}, d_{\mathrm{H}}=29.1 \mathrm{~nm}, d_{\mathrm{L}}=85.6 \mathrm{~nm}$.

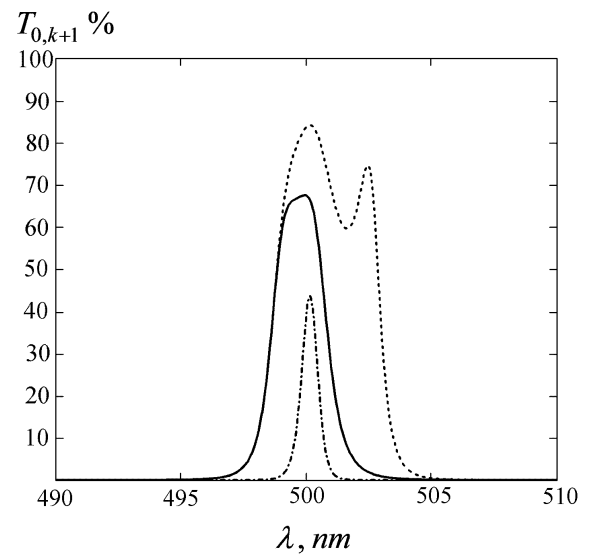

Fig. 4. Transmittance $T_{0, k+1}$ of three $k$-layer coatings at $\tilde{n}_{\mathrm{H}}=4.3-i 0.0015, \tilde{n}_{\mathrm{L}}=1.46-i 0.0001, \lambda_{0}=500 \mathrm{~nm}$ :

a) $1\left|\mathrm{HLH} \frac{4 d_{s} n_{\mathrm{L}}}{\lambda_{0}} \mathrm{~L}(\mathrm{HL})^{3} \mathrm{H} \frac{4 d_{m} n_{\mathrm{L}}}{\lambda_{0}} \mathrm{~L}(\mathrm{HL})^{3} \mathrm{H} 2 \mathrm{LHLH}\right| 1.52-$ dotted curve $\left(k=23, s=4, m=12, u=20 ; d_{s}=171.6 \mathrm{~nm}\right.$, $\left.\left.d_{m}=171.7 \mathrm{~nm}\right), d_{u}=171.2 \mathrm{~nm} ; d_{\mathrm{H}}=29.1 \mathrm{~nm}, d_{\mathrm{L}}=85.6 \mathrm{~nm}\right) ;$

b) filter (16) - solid curve;

c) filter (17) - dash-dotted curve. 


\section{O. P. KUSHNIR}

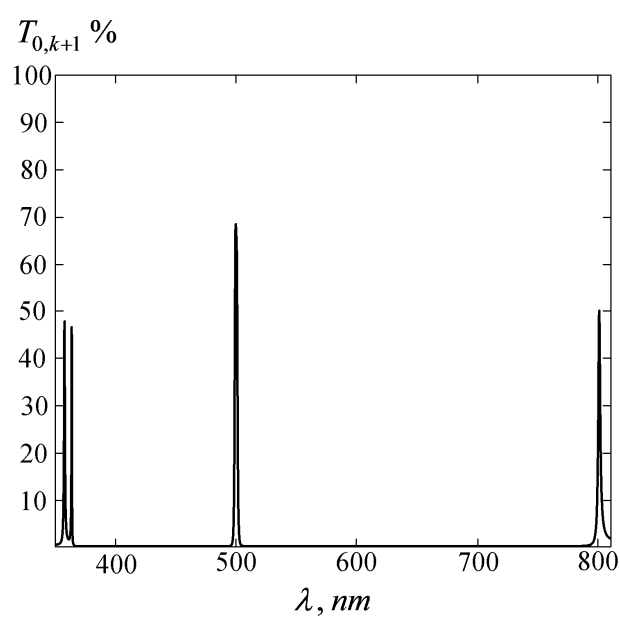

a)

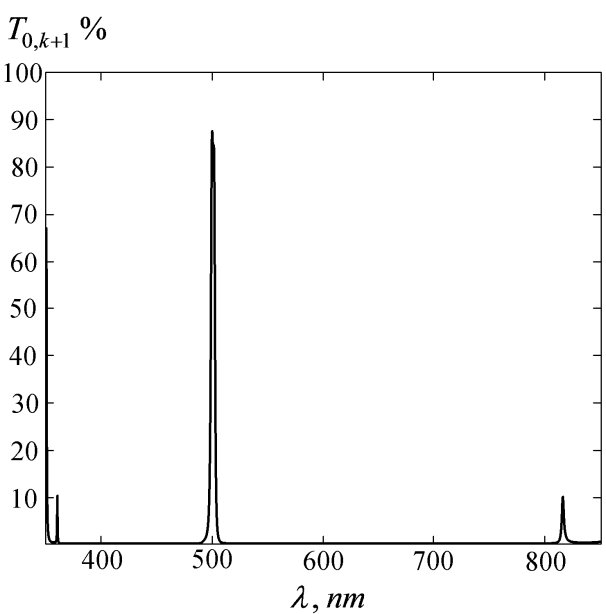

b)

Fig. 5. Transmittance $T_{0, k+1}$ of two interference coatings: a) filter (16); b) filter (18).

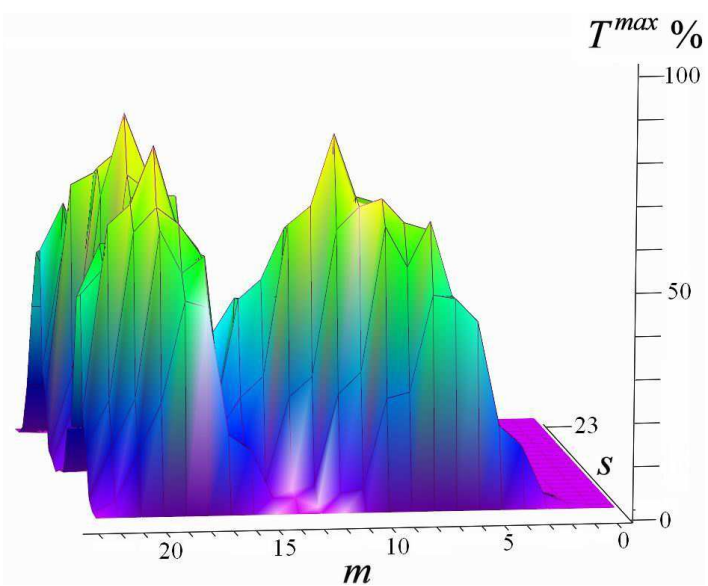

Fig. 6. Maximum transmittance $T^{\max }$ (among the transmittances $T_{0, k+1}$ of twenty-three layer coatings (15) with a halfwave layer $u$ and two layers $s, m$ with thicknesses $d_{s, m}$ (14) calculated for all possible numbers $u$ ) versus numbers $s, m$ at $\tilde{n}_{\mathrm{H}}=4.3-i 0.0015, \tilde{n}_{\mathrm{L}}=1.46-i 0.0001, \lambda_{0}=500 \mathrm{~nm}, k=23, d_{\mathrm{H}}=29.1 \mathrm{~nm}, d_{\mathrm{L}}=85.6 \mathrm{~nm}$.

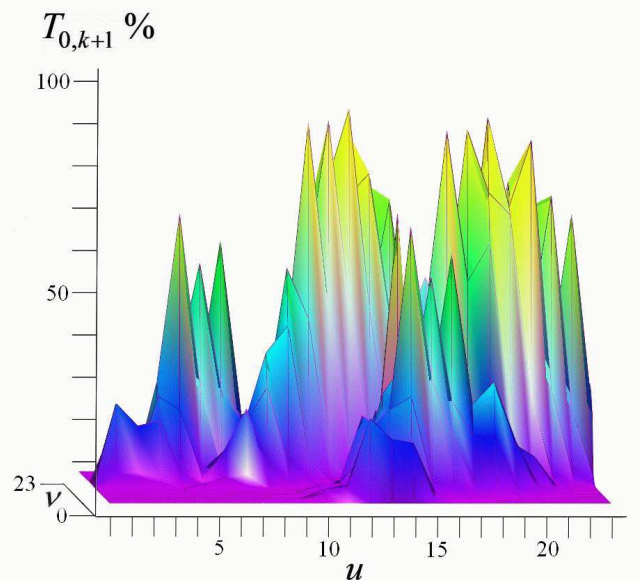

a)

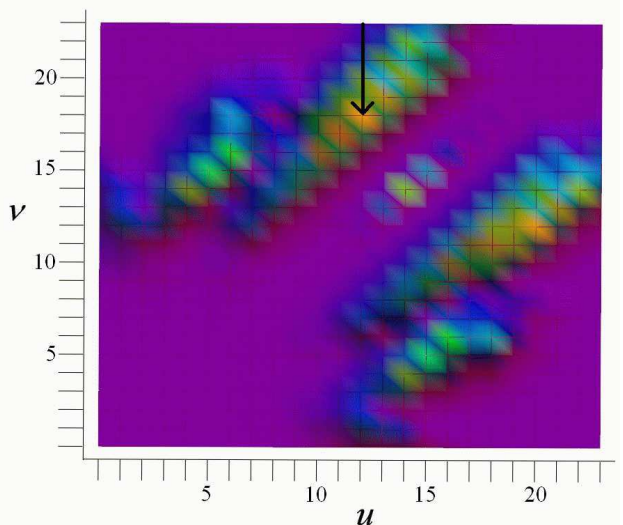

b)

Fig. 7. Transmittance $T_{0, k+1}(k=23)$ of the twenty-three-layer coating (15) versus numbers of two layers $u, \nu$, whose thicknesses are changed to $2 d_{\mathrm{L}, \mathrm{H}}$, and thicknesses $d_{s, m}$ are determined according to $(14)$ at $\tilde{n}_{\mathrm{H}}=4.3-i 0.0015, \tilde{n}_{\mathrm{L}}=1.46-i 0.0001$, $\lambda_{0}=500 \mathrm{~nm}, d_{\mathrm{H}}=29.1 \mathrm{~nm}, d_{\mathrm{L}}=85.6 \mathrm{~nm}, s=4, m=22$. The arrow in fig. b) indicates the pair of numbers $u, \nu$, which corresponds to the highest value $T_{0, k+1}$. 
Such calculations can also be performed for coatings with a different number of quarter-wave layers. Moreover, a decrease in the number of layers will lead to an increase in the bandwidth and to a decrease in the optical density of the filter in the rejection band [11]. With an increase in the number of quarter-wave layers, there is not only a narrowing of the passband, but also a decrease in the transmittance of the filter (Fig. 4 dash-dotted curve). The reason for the decrease in the transmittance in this case, as well as in the case of choosing a larger thickness $d_{u}$ (for example, $d_{u}=4 d_{\mathrm{L}, \mathrm{H}}$ in Figs. 2a, 3a), is an increase in the total thickness of the low absorbing coating.

A similar pattern is observed for the method of achieving high transmittance $\mathrm{b}$ ). To simplify the search for the best result, it is advisable to consider layers with numbers $u, \nu$ as half-wave spacers of the corresponding material with thickness $2 d_{\mathrm{L}, \mathrm{H}}$. The next step is to choose a pair of numbers $u, \nu$ based on the dependence $T_{0, k+1}(u, \nu)$ (Fig. 7) at which the maximum transmittance is achieved. One of the best results for method b) is twenty-three-layer filter (Fig. 5b):

$$
1 \mid \operatorname{HLH} \frac{4 d_{s} n_{\mathrm{L}}}{\lambda_{0}} \mathrm{~L}(\mathrm{HL})^{3} \text { H } 2 \mathrm{~L}(\mathrm{HL})^{2} \mathrm{H} 2 \mathrm{LHL} H \frac{4 d_{m} n_{\mathrm{L}}}{\lambda_{0}} \mathrm{LH} \mid 1.52
$$

at $\tilde{n}_{\mathrm{H}}=4.3-i 0.0015, \tilde{n}_{\mathrm{L}}=1.46-i 0.0001, s=4, m=22, u=12, \nu=18$. Using (14), the thicknesses of layers $s$ and $m$ are calculated: $d_{s}=171.5 \mathrm{~nm}, d_{m}=175.7 \mathrm{~nm}$. Here, the thicknesses of the quarter-wave layers $\mathrm{H}$ and $\mathrm{L}$ are equal to: $d_{\mathrm{H}}=29.1 \mathrm{~nm}, d_{\mathrm{L}}=85.6 \mathrm{~nm}$ and the thicknesses of the half-wave layers $u$ and $\nu$ are equal to: $d_{u}=d_{\nu}=171.2 \mathrm{~nm}$.

In method c), it is necessary to consider three layers with numbers $u, \nu, w$, as half-wave spacers of the corresponding material with thickness $2 d_{\mathrm{L}, \mathrm{H}}$. One of the highest values $T_{0, k+1}(u, \nu, w)$ is achieved for the seventeen-layer filter $(k=17)$ :

$$
\text { 1| } \frac{4 d_{s} n_{\mathrm{H}}}{\lambda_{0}} \mathrm{HLHL} 2 \mathrm{H}(\mathrm{LH})^{2} 2 \mathrm{LHLH} 2 \mathrm{LHL} \frac{4 d_{m} n_{\mathrm{H}}}{\lambda_{0}} \mathrm{H} \mid 1.52
$$

at $\tilde{n}_{\mathrm{H}}=2.3-i \kappa, \tilde{n}_{\mathrm{L}}=1.35-i \kappa, s=1, m=17, u=5, \nu=10, w=14$. According to (14), thicknesses of layers $s$ and $m: d_{s}=108.8 \mathrm{~nm}, d_{m}=108.6 \mathrm{~nm}$ are calculated at $\kappa=0.0015$. Here, the thicknesses of the quarter-wave layers $\mathrm{H}$ and $\mathrm{L}$ are equal to: $d_{\mathrm{H}}=54.3 \mathrm{~nm}, d_{\mathrm{L}}=92.6 \mathrm{~nm}$ and the thicknesses of the half-wave layers $u, \nu$ and $w$ are equal to: $d_{u}=108.7 \mathrm{~nm}, d_{\nu}=d_{w}=185.2 \mathrm{~nm}$.

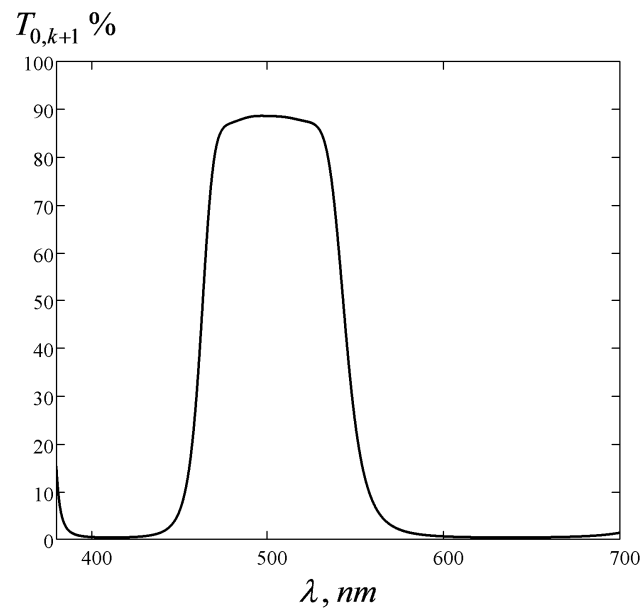

Fig. 8. Transmittance $T_{0, k+1}$ of the filter (19).

Compared to the filters calculated in methods a) and b), method c) makes it possible to obtain filters with a higher maximum transmittance even at the higher absorption of layers (Fig. 8). Figure 1 (solid curve) shows the dependence of the maximum filter transmittance $T_{0, k+1}^{\max }(19)$ at wavelength $\lambda_{0}$ versus the exti- nction coefficient $\kappa$, that is the same for both materials. This dependence shows the possibility of designing interference filters using materials whose extinction coefficient is relatively high.

\section{CONCLUSIONS}

An analysis of the obtained dependences of the transmittance of a multilayer coating formed on the basis of two arbitrary low absorbing materials shows the impossibility of achieving its high value by determining the thicknesses of only two layers, when all other layers are quarter-wave. Instead, $100 \%$ transmittance can be achieved for a similar transparent coating by determining the thicknesses of only two layers, which is confirmed by the conclusions $[9,10]$. Based on the results obtained in this work, we can conclude that it is necessary to change the thicknesses of three (or more) layers of a low absorbing coating such as an interference mirror (15) in order to achieve high transmittance. The proposed calculation method using two or more halfwave spacers makes it possible to achieve high transmittance for chosen wavelength, which may have practical application. 


\title{
O. P. KUSHNIR
}

Advantages of narrow-band filters based on low absorbing materials designed using this method are:

1) the use of only two materials;

2) the possibility to reduce the filter bandwidth by increasing the number of quarter-wave layers. However, such an increase in the number of quarter-wave layers with a constant number of non-quarter-wave layers leads to a decrease in the transmittance, which is a limitation of this method.
[1] A. Thelen, Design of Optical Interference Coatings (McGraw-Hill, New York, 1989).

[2] H. A. Macleod, Thin-Film Optical Filters, 4th ed. (Taylor \& Francis Group, Boca Raton, 2010).

[3] A. Thelen, J. Opt. Soc. Am. 56, 1533 (1966); https: //doi.org/10.1364/JOSA.56.001533.

[4] C. Jacobs, Appl. Opt. 20, 1039 (1981); https://doi.or g/10.1364/AO.20.001039.

[5] P. Baumeister, Opt. Express 9, 652 (2001); https://do i.org/10.1364/0E.9.000652.

[6] P. Baumeister, Appl. Opt. 21, 2965 (1982); https://do i.org/10.1364/A0.21.002965.

[7] S. D. Smith, J. Opt. Soc. Am. 48, 43 (1958); https: //doi.org/10.1364/JOSA. 48.000043.

[8] I. Ya. Yaremchuk, V. M. Fitio, Ya. V. Bobitski, OptoElectron. Rev. 19, 50 (2011); https://doi.org/10.247 8/s11772-011-0008-4.

[9] J. Mouchart, Appl. Opt. 16, 3237 (1977); https://doi. org/10.1364/A0.16.003237.

[10] O. P. Kushnir, Ukr. J. Phys. Opt. 10, 82 (2009); https: //doi.org/10.3116/16091833/10/2/82/2009.

[11] O. P. Kushnir, J. Phys. Stud. 14, 4401 (2010).
[12] O. P. Kushnir, J. Opt. A: Pure Appl. Opt. 11, 085704 (2009); https://doi.org/10.1088/1464-4258/ $11 / 8 / 085704$.

[13] P. Wu et al., Results Phys. 16, 102952 (2020); https: //doi.org/10.1016/j.rinp. 2020.102952.

[14] J. Mu et al., Appl. Phys. Lett. 102, 213105 (2013); ht tps://doi .org/10.1063/1.4807925.

[15] J. Hendrickson, N. Nader, B. Zhang, H. Chen, J. Guo, in Frontiers in Optics 2014 (Optical Society of America, 2014), paper JW3A.34; https://doi.org/10.1364/ FI0. 2014. JW3A.34.

[16] X. Wang et al., Sci. Rep. 5, 8503 (2015); https://doi. org/10.1038/srep08503.

[17] V. Fitio, Ya. Bobitski, in Proceedings of LFNM 2005 (2005), p. 163; https://doi.org/10.1109/LFNM. 2005. 1553218.

[18] Sh. A. Furman, A. V. Tikhonravov, Basics of Optics of Multilayer Systems (Edition Frontières, Gif-sur-Yvette, 1992).

[19] I. V. Grebenshchikov, A. G. Vlasov, B. S. Neporent, N. V. Sujkovsky, Non-reflective Coatings on Optical Materials (OGIZ, Moscow, 1946).

\section{ЗБІЛЬШЕННЯ ЕНЕРГЕТИЧНОГО КОЕФЦЦЕНТА ПРОПУСКАННЯ СЛАБОПОГЛИНАЛЬНОГО БАГАТОШАРОВОГО ПОКРИТТЯ}

\author{
О. П. Кушнір \\ Лъвівсъкий начіоналъний аграрний університет, \\ кафедра фізики та інженерной механіки, \\ вул. Володимира Великого, 1, Дубляни, Лъвівсъка обл., 80381, Украӥна
}

Більшість розроблених методів проектування вузькосмугових фільтрів базуються на використанні лише прозорих матеріалів для шарів. Проте не завжди є змога використовувати матеріали, які б мали для заданої довжини хвилі дуже низький рівень поглинання. Використання слабопоглинальних матеріалів із показником поглинання понад $10^{-3}$ призводить до значного зменшення максимального пропускання фільтра, що був розрахований для прозорих матеріалів.

У цій роботі розроблено метод досягнення високого коефіцієнта пропускання слабопоглинального покриття з використанням трьох або більше нечвертьхвильових шарів. Цей метод базується на використанні встановлених аналітичних виразів для комплексних значень товщини двох довільних шарів слабопоглинального багатошарового покриття, за яких досягається нульове значення коефіцієнта відбивання. На основі цих співвідношень запропоновано числову процедуру пошуку товщини ще одного або більше шарів покриття, які дозволяють отримати високий коефіцієнт пропускання для вибраної довжини хвилі. Такий підхід дає змогу одержати високі значення коефіцієнта пропускання для вузькосмугових фільтрів із довільним вибором слабопоглинальних матеріалів для них і з довільною кількістю шарів.

Аналіз установлених залежностей для коефіцієнта пропускання багатошарового покриття, утвореного на основі двох довільних слабопоглинальних матеріалів, указує на неможливість досягнути його високого значення визначенням товщини лише двох шарів, коли всі інші залишаються чвертьхвильовими. Водночас для аналогічного прозорого покриття можна отримати $100 \%$ пропускання за рахунок визначення товщини двох шарів. Одержані в цій роботі результати вказують на необхідність зміни товщини трьох (або більше) шарів слабопоглинального покриття типу інтерференційне дзеркало для досягнення неблизького до нуля пропускання. Запропонований метод розрахунку з використанням двох або більше півхвильових спейсерів дає змогу домогтися високого коефіцієнта пропускання для вибраної довжини хвилі, що може мати практичне застосування.

Ключові слова: слабопоглинальне багатошарове покриття, інтерференційний смуговий фільтр, інтерференційне дзеркало, півхвильовий спейсер, високий коефіцієнт пропускання. 